\title{
W4-1
}

\section{NLR の活性化機構と病原体感染とのかかわり}

\section{鈴木敏彦}

\section{(琉球大学 大学院医学研究科)}

病原体パターン受容体 Nucleotide-binding, oligomerization domain (NOD)-like receptor (NLR) ファ ミリーのいくつかは，細胞内カスパーゼー1の活性化を誘導し，宿主炎症応答を制御することが明らか になってきている．NLRC4 は細菌のべん毛や分泌装置由来のタンパクを認識する．一方で，NLRP3 は細菌, ウイルス等の病原体のみならず, 生体内危険因子（尿酸結晶, コレステロール結晶等）も認識 してカスパーゼ-1 を活性化する．また，AIM2 は 2 本鎖 DNA を認識するとされている。このように， NLR はそれぞれ異なった刺激因子を認識していると考えられるが，その分子機構は未だよくわかって いない，我々は，グラム陰性病原細菌の感染に伴って誘導されるカスパーゼ-1の活性化機構を，菌お よび宿主 NLR の両面から調べてきた．その中で，菌が分泌する因子が NLR によるカスパーゼ-1 活性 化を阻害することを見出し, 菌が免疫応答を回避する可能性が示唆されている. 本セミナーでは細菌感 染とNLR との関わりについて，我々の研究知見を交えながら紹介したい. 